\title{
Islamisasi Metode Berpikir: Sebuah Pemikiran Awal
}

MF. Zenrif

Dosen tetap Jurusan

Syari'ah STAIN Malang

\section{Iftitah}

Tidak sedikit masyarakat kampus, baik di lingkungan Departemen Agama atau Departemen Pendidikan Nasional, yang belum atau sengaja tidak memahami perlunya islamisasi ilmu pengetahuan. Padahal, di dunia ilmu pengetahuan global, banyak pakar meyakini bahwa sejak paruh terakhir abad ke20 merupakan kebangkitan kembali Islam (the renaissance of Islant) yang setidaknya ditandai dengan timbulnya semangat islamisasi ilmu pengetahuan, ekonomi, sosial, politik dan sebagainya. Keberhasilan islamisasi ini bahkan dinilai oleh GB. Shaw sebagai salah satu indikasi bahwa Islam adalah agama yang mempunyai kapasitas asimilasi terhadap perubahanperubahan yang dapat mengantarkan dunia pada kebahagiaan. ${ }^{1}$

Penilaian Shaw tersebut tidak berlebihan, sebab sejak paruh kedua abad ke-20 isalmisasi dalam berbagai bidang menampakkan asimilasinya dengan kentalnya perubahan-perubahan. Sekalipun geliat islamisasi tersebut belum menemukan formatnya 
yang ideal sehingga berakibat biasnya gerakan islamisasi, namun gerakan islamisasi itu pada akhirnya mampu menembus lapangan islamisasi epistemologi. Rekonstruksi epistemologi, dalam hal ini, dianggap penting dan esensial karena dapat mempermudah asimilasi nilai-nilai Islam ke dalam wacana keilmuan secara menyeluruh. Pada tataran ini, islamisasi metode berpikir dan penelitian, sebagai tumpuan pertumbuhan dan pengendalian ilmu, menjadi sangat urgen dilakukan.

\section{Mengapa Perlu Islamisasi Metode?}

Sebagaimana disebutkan sebelumnya, bahwa metode berpikir dan penelitian merupakan tumpuan dari pengembangan ilmu pengetahuan, maka metode berpikir dan penelitian sesungguhnya merupakan bentuk aplikatif dari seluruiti paradigma dan world viei aliran-aliran ilmu pengetahuan. Ali Syari'ati, sebagaimana dikutip Mukti Ali, menyatakan "bahwa faktor yang menyebabkan kemunduran dan kejumudan dalam peradaban, pemikiran dan kebudayaan Barat yang berlangsung hingga seribu tahun, pada abad-abad pertengahan, adalah akibat dari penggunaan metode pemikiran analogis dari Aristoteles: Dikäla cara melihat obyek dan realitas itu berubah, maka sains, masyarakat dan dunia Barat juga berubah. ${ }^{2}$ Dengan demikian, rekonstruksi metodologi sangat menentukan gerakan pembaharuan suatu bangsa.

Namun perlu dicatat, bahwa metode berpikir yang dikembangkan Barat dengan pradigma materialismenya, telah membawa Barat pada krisis global yang tiada taranya. Capra dalam hal ini mengatakan bahwa pada awal dua dasawarsa terkahir abad ke-20 manusia berada dalam sebuah krisis global yang serius, yaitu krisis kompleks dan multidimensional yang sendi-sendinya menyentuh setiap aspek kehidupan, kesehatan, dan mata pencaharian, kualitas lingkungan dan hubungan sosial, ekonomi, teknologi dan politik. Krisis ini, masih menurut Capra, menyangkut dimensidimensi intelektual, moral dan spritual; sebua krisis yang belum pernah terjadi sebelumnya dalam catatan sejarah umat manusia. ${ }^{3} \mathrm{Hal}$ ini merupakan alasan pertama mengapa kita perlu melakukan islamisasi metode berpikir dan penelitian.

Alasan kedua, bahwa debat metode berpikir dan penelitian yang selama ini terjadi, antara kecenderungan kuantitatif dan : kualitatif serta seperangkat pendekatannya, menurut Munir Mulkhan, masih bersifat ideologis dan politis, daripada muatan ilmiah yang 
dikadungnya. ${ }^{4}$ Jika tesis Mulkhan ini benar, maka sesungguhnya setiap metode berpikir dan penelitian yang dikembangkan sangat bergantung pada paradigma dan world view yang melandasinya. Karena Barat mempunyai paradigma dan world view tentang seluruh realitas berbeda dengan Islam, kita harus mengambil paradigma dan world view Islam tentang seluruh realitas, sekalipun bukan berarti meninggalkan pentingnya pemahaman kita tentang paradigma dan world view Barat tentang seluruh realitas. Sebab, seperti dikatakan Nasution, metode Barat itu bagaimanapun masih dapat dipergunakan hingga saat ini. ${ }^{5}$

\section{Bagaimana Melakukan Islamisasi Metode?}

Setiap gerakan pasti membutuhkan sebuah identias yang dapat membedakan antara dirinya dengan lainnya. Identitas islamisasi metode berpikir dan penelitian setidaknya diladaskan pada paradigma dualitas dalam memandang realitas obyek. Oleh karenanya, islamisasi metode setidaknya mempunyai karakteristikkarakteristik:

1. Karakteriktis Dualitas

Karakteristik dualitas ialah karakteristik yang menjadi landasan dari islamisasi metode. Ia meliputi konsep dualitas yang mengintegralkan ide-ide dunia dan norma agama, rasionalisme dan empirisme, "fenomenologisme" dan "simbolisme" dan seterusnya. Dengan demikian, metode yang dihasilkan oleh islamisasi metode ini tidak memberikan titik pemisah antara ilmu-ilmu yang dihasilkan oleh ide dunia dan ide agama.

Dalam konteks yang disebutkan terkahir ini, metode yang dihasilkan islamisasi tidak menafikan adanya penglaman dan pengetahuan Barat, karena sekalipun pengalaman dan penegtahuan tersebut dihasilkan di luar Islam, ia masih bisa didekatkan dengan konsep universalisme Islam, mencakup seluruh sunah penciptaan alam (sunnatullah).

2. Karakteristik Mutawassith

Apabila dalam karakteristik dualitas dapat dilihat adanya keterpaduan antara ide-ide dunia dan norma agama, pada karakteristik mutawassith islamisasi metode secara istigamah mengkritisi dan memberikan nilai-nilai terhadap hasil pemikiran dan ilmu pengetahuan (Barat), terutama yang berkaitan dengan pandangan dunia tentang realitas.

Dengan demikian, karakteristik mutawassith mempunyai arti pengambilan jalan.tengah yang dapat menjembatani dua metode yang ekstrim, metode 
doktriner yang dikembangkan oleh ulama-ulama salaf, dan materialisme yang dikembangkan Barat; atau antara metode normatif dan realis-materialistik. Karakteristik ini memberikan keseimbangan antara ide-ide agama dan ide-ide dunia.

\section{Karakteristik Formulatif}

Dalam karakteristik mutanassith didapatkan bahwa upaya islamisasi metode berpikir dan penelitian berupaya membentuk sebuah konsep yang menengah-nengahi antara dua eks rimitas. Langkah selanjutnya ialah merekonstruksi sebuah formula yang dengannya antara ide agam dan ide duania dapat diintegralkan. Sehingga, upaya islamisasi tidak hanya mendekonstruksi penilaian provanitas Barat dan normativitas ulama salaf, lebih dari itu islamisasi harus mampu mereformulasikan seluruh pandangan tentang realitas sesuai dengan apa yang dikehendaki oleh ide agama (wahyu).

Karakteris ik tersebut akan dapat membedakan sebuah cara berpikir atau metode penelitian yang berbeda dengan lainnya, baik yang pemah dilakukan ulama salaf atau yang dikembangkan Barat. Sedangkan wujud dari identias dan karakteristik tersebut dapat diaplikasikan dalam bentuk pendekatan yang dikembangkan metode yang terislamisasikan (islamized method) yang dilandaskan pada Pendekatan Teologis.

Teologi atau biasa ditulis "Theologi" dan "Theology" adalah ilmu pengetahuan yang membahas tentang ajaran-ajaran dasar kepercayaan dari suatu agama. Setiap umat yang ingin menyelami seluk beluk agamanya secara mendalam, perlu mempelajari teologi yang melandasi keyakinan yang dianut agamanya agar tidak mudah diombang-ambingkan oleh peredaran zaman. ${ }^{7}$ Teologi yang dimaksudkan tadi ialah salah ilmu pengetahuan Islam (klasik) yang juga disebut dengan Ushuluddin, Ilmu Tauhid, atau Ilmu Kalam.

Pendekatan Teologis bukan dalam pengertian di atas. Ia merupakan sebuah istilah yang menunjukkan pada sebuah keyakinan religi yang melandasi seluruh worid view tentang realitas. Keyakinan ini, menjadi landasan dari seluruh aspek dari dan sckaligus menjadi ciri khas bagi keilmuan Islam. Dengan lain kata, teologi atau tauhid merupakan tumpuan Islam dalam memandang realitas. Oleh karena itu, Pendekatan Teologis menjadikan keyakinan religi sebagai manbaj al-fiker, yang dengannya dibentuk Islamic World View atau weltanchaunng of Islam. Manbaj ini bisa bersifat universal, seperti ajaranajaran Islam yang tidak terbatas oleh 
ruang dan w̦aktu, atau bersifat lokal dan temporal.

Manhaj yang dibentuk ini pada gilirannya akan bersifat komprehensif dan memenuhi kebutuhan keseimbangan. Komprehensif mencakup seluruh aspek kehidupan manusia dalam dimensi panjang, lebar dan dalam. Keseimbangan mencakup keseimbangan ruh dan jasad, akal dan kalbu, duniawi dan ukhrawi, perumpaan dan realitas, dan seterusnya. ${ }^{8}$

\section{IKHTITAM}

Dari semua yang dijelaskan di atas, saya ingin menegaskan bahwa islamisasi metode berpkir dan penelitian dapat diartikan bahwa metode yang dikembangkan Barat tidak dianggap bagian dari pengetahuan Islam (dengan "I" besar), tetapi ia dapat dikategorikan dalam pengetahuan islam (dengan "i" kecil) yang berarti islami. Oleh sebab itu, islamisasi dalam pengertian ini mestinya dipandang sebagai sebuah gerakan rekonstruksi metode berpikir dan penelitian. Karenanya baik metode berpikir dan penelitian " yang dikembangkan dalam Islam "Klasik" maupun Barat "Modern" perlu direkonstruksi untuk mencapai sebuah metode yang diharapkan oleh Islam.

Terakhir, saya menyadari bahwa pikiran ini belum mencapai titik terang sebuah islamisasi metode berpikir dan penelitian seperti yang diharapkan.Namun tob demikian, pemikiran awal ini perlu didiskusikan secara mendalam dan berkelanjutan, sebab tidak ada pengetahuan yang di"sulap" sedemikian rupa sehingga secara instan sebuah pemikiran mencapai pada puncak es peradabannya. Tentu saja, dialog yang secara simultan mengenai hal ini pada akhirnya akan memberikan kontribusi yang besar bagi terciptanya sebuah perdaban yang islami, dan saya yakin tentang hal ini.

\section{DAFTAR PUSTAKA}

A. Mukti Ali, "Metodologi Ilmu Agama Islam," dalam Taufik Abdullah dan Rusli Karim (ed.), Metodologi Penelitian Agama: Sebuah Pengantar (Cet. III; Yogyakarta: Tiara Wacana, 1991). , Etika Agama dalam Pembentukan Keperibadian Nasional dan Pemberantasan Kemaksiatan dari Segi Agama Islam (Cet. I; Yogyakarta: Yayasan Nida, 1969)

Fritjof Capra, "Science, Society and the Rising Culture", diterjemahkan M. Thoyibi dengan judul, Tititk Balik Peradaban Sains, Masyarakat, dan Kebangkitan Kebudayaan (Cet. I; Yogyakarta; Yayasan Bentak Budaya, 1997). 
Harun Nasution, Teologi Islam: Aliran-aliran, Sejarab, Analisa Perbandingan (Cet. V; Jakarta: UI Press. 1986).

Muhammad Iqbal, Recontsruction of Religious Thought (t.d.).

Munir Mulkhan, Paradigma Intelektual Muslim: Pengantar Filsafat Pendidikan Islam dan Dakıvab (Yogyakarta: Sipress, 1994).

Saiful Muzani, Islam rasional: Gagasan dan Pemikiran Prof. Dr. barun Naution (Cet. I; Bandung: Mizan, 1995).

\section{Footnotes}

'Lihat A. Muktí Ali,

Etika Agama dalam Pembentukan Keperibadian Nasional dan Pemberantasan Kemaksiatan dari Segi Agama Islam

(Cet. I; Yogyakarta: Yayasan Nida, 1969), h. 38.

${ }^{2}$ Lihat A. Mukti Ali, "Metodologi Ilmu Agama Islam," dalam Taufik Abdullah dan Rusli Karim (ed.),

Metodologi Penelitian Agama: Sebuah Pengantar

(Cet. III; Yogyakarta: Tiara Wacana, 1991), h. 44.

${ }^{3}$ Baca Fritjof Capra, "Science, Society and the Rising Culture", diterjemahkan M. Thoyibi dengan judul,

Titik Balik Peradaban Sains, Masyarakat, dan Kebangkitan Kebudayaan

(Cet. I; Yogyakarta; Yayasan Bentak Budaya, 1997), h. 3.

${ }^{4}$ Lihat Munir Mulkhan,

Paradigma Intelektual Muslim: Pengantar Filsafat Pendidikan Islam dan Dakwah

(Yogyakarta: Sipress, 1994), h. 134.

${ }^{5}$ Baca Saiful Muzani,

Islam rasional: Gagasan dan Pemikiran Prof. Dr. harun Naution

(Cet. I; Bandung: Mizan, 1995), h. 416-421.

${ }^{\circ} \mathrm{Hasil}$ pemaduan ini dapat dilihat dalam pemikiran Muhammad Igbal, Recontsruction of Religious Thought (t.d.), h. 7, 53, 54, dan 92.

${ }^{7}$ Harun Nasution, Teologi Islam: Aliran-aliran, Sejarah, Analisa Perbandingan (Cet. V; Jakarta: UI Press. 1986), h. ix.

"Master piece logika ini baca dalam Yusuf Qardhawi, "Kaifa Nata'ammal Ma'a al-Sunnah alNabawiyyah," diterjemahkan oleh Muhammad al-Bakir dengan judul, Bagaimana MemahamiHadis Nabi saw. (Cet. II; Bandung: Penerbit Kharisma, 1993), h. 18-21. 